almost a twofold higher mortality by 65 than those who continued working (1.89, 1.58 to 2.27$)$. The mortality by 65 of employees who retired at 60 was similar to those who continued working at $60(1.04,0.82$ to 1.31$)$.

\section{Discussion}

The long term survival of people who retire early at ages 55 or 60 is no better than that of those who retire at 65 . On the contrary, mortality improved with increasing age at retirement for people from both high and low socioeconomic groups, defined according to employment grade. It is reasonable to assume that some workers retired at 55 because of failing health, as the mortality for this group in the first 10 years after retirement was almost twofold higher than that of their peers who continued working. The health status of those who retired at 60 , however, was similar to those who continued working at 60 .

The finding of lower survival among employees of low socioeconomic status, regardless of age at retirement, is not unexpected and is consistent with other studies. ${ }^{8-11}$ Similarly, it was not unexpected that men had statistically higher mortality than women and that those retiring in more recent years had better survival.

Several studies found lower survival among those retiring early and attributed this to poor health status forcing early retirement. ${ }^{13}$ Our study confirmed the finding of lower survival in people who take early retirement at age 55 , but we did not find evidence of lower survival among those who retired at 60. To reduce potential bias due to differences in health status between early and late (age 65) retirees, we excluded survival for the first 10 years of follow-up after retirement at 55 and for the first five years after retirement at 60 for early retirees. Although the effect of early retirement because of failing health may not be totally eliminated, survival rates remained significantly greater for those who retired at 65 compared with those who retired at 55 . The difference in survival between those who retired between 60 and 65 was, however, small and not statistically significant.

\section{What is already known on this topic}

There is a widespread perception that early retirement is associated with longer life expectancy and later retirement is associated with early death

No consensus has been reached on the comparative survival or mortality of people who retire early or late

\section{What this study adds}

Early retirement at 55 or 60 is not associated with increased survival

Employees who retired at 60 had similar survival to those who retired at 65

Differences in mortality could not be attributed to the effects of sex, year of entry to the study, or socioeconomic status

Contributors: See bmj.com.

Funding: None.

Competing interests: None declared.

Ethical approval: Not required.

1 Haynes SG, McMichael AJ, Tyroler HA. Survival after early and normal retirement. J Gerontol 1978;33:269-78.

2 Ekerdt DJ, Baden R, Bosse R, Dibbs E. The effect of retirement on physical health. Am J Public Health 1983;73:779-83.

Morris JK, Cook DG, Shaper AG. Loss of employment and mortality. BMJ 1994;308:1135-9.

Trichopoulos D. Any questions? BMJ 1996:312:632

Padfield A. Myths in medicine. BMJ 1996;312:1611.

6 Lin S. Optimum strategies for creativity and longevity. 2002. http://www. Lin S. Optimum strategies for creativity and longevity. 2002. http://www. 2005).

7 Joyner RE, Pack PH. The Shell Oil Company's computerized health surveillance system.J Occup Med 1982;24: 812-4.

Lantz PM, House JS, Lepkowski JM, Williams DR, Mero RP, Chen J. Socioeconomic factors, health behaviors, and mortality: results from a nationally representative prospective study of US adults. JAMA 1998;279:1703-8.

9 Chandola T. Social class differences in mortality using the new UK national statistics socio-economic classification. Soc Sci Med 2000;50:641-9.

10 Mackenbach JP, Bos V, Andersen O, Cardano M, Costa G, Harding S, et al. Widening socioeconomic inequalities in mortality in six Western European socioecos

11 Muntaner C, Hadden WC, Kravets N. Social class, race/ethnicity and allcause mortality in the US: longitudinal results from the 1986-1994 national health interview survey. Eur J Epidemiol 2004;19:777-84 (Accepted 16 August 2005)

doi 10.1136/bmj.38586.448704.E0

\title{
Twenty five years of HIV infection in haemophilic men in Britain: an observational study
}

\author{
Caroline A Sabin, Andrew N Phillips, Thynn Thynn Yee, Anja Griffioen, Christine A Lee
}

\begin{abstract}
The first HIV seroconversion in the United Kingdom in a man with haemophilia was in $1979 .{ }^{1}$ After HIV was identified, measures were taken to remove the risk of HIV transmission via blood products, and since 1986 no HIV infections have occurred through this route in the developed world. The epidemic is now 25 years old in haemophilic men. Although the introduction of highly active antiretroviral therapy (HAART) has altered the course of HIV infection, many haemophilic men died before this became available. It is important to monitor those remaining alive to determine their long term outcomes and to assess the impact of coinfection with hepatitis $\mathrm{C}$ virus.
\end{abstract}

\section{Participants, methods, and results}

The Royal Free Hospital haemophilia cohort, consisting of 111 men with haemophilia infected with HIV after treatment with contaminated clotting factor concentrates (median age 22 (range 2-77) years at infection), has been described previously. ${ }^{2}$ All are coinfected with hepatitis $\mathrm{C}$ virus. Follow-up timecalculated from seroconversion date to the date of death, last clinic visit (for those lost to follow-up), or

This article was posted on bmi.com on 16 September 2005: http://bmj.com/cgi/doi/10.1136/bmj.38604.468785.DE
Department of Primary Care and Population Sciences, Royal Free and UC Medical School, London NW3 2PF

Caroline A Sabin professor Andrew N Phillips professor

continued over 
Haemophilia

Centre and

Haemostasis Unit,

Royal Free NHS

Trust, London

Thynn Thynn Yee

medical specialist

Anja Griffioen

database manager

Christine A Lee

professor

Correspondence to: C. A Sabin c.sabin@ pcps.ucl.ac.uk
Predicted and observed numbers of AIDS cases occurring by the end of each year in the Royal Free Hospital haemophilia cohort, $1985-2000$

\begin{tabular}{lcccccccc} 
& \multicolumn{8}{c}{ Calendar year } \\
\cline { 2 - 9 } & $\mathbf{1 9 8 5}$ & $\mathbf{1 9 8 6}$ & $\mathbf{1 9 8 7}$ & $\mathbf{1 9 8 8}$ & $\mathbf{1 9 8 9}$ & $\mathbf{1 9 9 0}$ & $\mathbf{1 9 9 5}$ & $\mathbf{2 0 0 0}$ \\
\hline Predicted $^{5}$ & 0 & 2 & 6 & 18 & 29 & 37 & 52 & 60 \\
\hline Observed $^{3}$ & 6 & 16 & 25 & 32 & 35 & 53 & 58
\end{tabular}

31 December 2004-ranged from 0.8 to 25.1 years (median 14.3). By 31 December 2004, 59 (53\%) men had developed AIDS and 74 (67\%) had died (54 after developing AIDS, 20 before AIDS). From 1996, when HAART was introduced, there have been only six new cases of AIDS but 20 deaths, compared with 53 AIDS cases and 54 deaths before 1996. Deaths since 1996 have been due to liver related causes (liver failure, cirrhosis, or hepatocellular carcinoma (7 deaths)), nonHIV related causes (5 deaths), HIV related causes (5 deaths), and unknown causes (3 deaths). Before 1996, $42(78 \%)$ deaths were due to HIV related causes and only five $(9 \%)$ due to liver related causes.

In 1989, using a method based on rates of CD4 cell count decline, we estimated that 60 men would have AIDS by 2000 (table). ${ }^{3}$ The observed numbers are remarkably consistent with these estimates, which is somewhat surprising as we had not anticipated the benefits of HAART. Possible explanations are that those who survived long enough to benefit from HAART had not been predicted to develop AIDS before 2000 in any case, and that any positive effects of HAART have been partly negated by the effects on survival of liver disease.

The 23 patients remaining under care at the centre (14 patients have transferred elsewhere) have been followed for a median of 22.7 (19.7-25.1) years. Most (20) have received HAART, 14 of whom had already had antiretroviral treatment when starting HAART. The 20 patients have received a median of seven (3-11) antiretroviral drugs and have been exposed to antiretroviral therapy for a median of 9.9 (1.0-16.8) years. Although these patients' treatment histories would now be considered suboptimal, all currently have an HIV RNA level $<50$ copies $/ \mathrm{ml}$ and their median CD4 cell count is $326(139-593) \times 10^{6}$ cells $/$ l. The three patients who have not received HAART have had stable CD4 counts $>200 \times 10^{6}$ cells $/$; viral loads have remained low in two patients, and moderate but stable (last viral load 18234 copies/ml) in the third.

\section{Comment}

A small proportion of haemophilic men infected with HIV 20-25 years ago remain alive and well. Advances in haemophilia care had increased life expectancy from 40 years in the 1960 s to 69 years by $1980 .{ }^{4}$ The HIV epidemic caused a reversal in these improvements that has been reversed only partially by HAART because coinfection with hepatitis $\mathrm{C}$ virus continues to cause deaths. ${ }^{5}$ Although treatment of hepatitis $\mathrm{C}$ is improving, responses remain poor among those coinfected with HIV. Continued development of new antiviral agents for both HIV and hepatitis $\mathrm{C}$ virus is essential to maintain the health of these patients.

\section{What is already known on this topic}

About a fifth of patients with haemophilia in the UK were infected with HIV between 1979 and 1985 after treatment with contaminated clotting factor concentrates

Coinfection with hepatitis $\mathrm{C}$ virus has contributed to mortality among these men

\section{What this study adds}

A small proportion of haemophilic men infected with HIV 20-25 years ago remain alive and well, but there has been an increasing number of deaths from liver related causes in this patient group as a consequence of coinfection with hepatitis $\mathrm{C}$ virus

Contributors: CAS, CAL, and ANP produced the initial concept and design of the study. CAS analysed and interpreted the data and wrote the manuscript, and is guarantor for the study. ANP helped prepare the manuscript. AG and TTY were involved with coordinating the study and helped to create and clean the datasets. All authors commented on the interpretation of data and approved the final version of the manuscript.

Funding: The Royal Free haemophilia cohort study has in the past received funding from the Medical Research Council, UK (Grant No G9722348).

Competing interests: None declared.

Ethical approval: Not needed since all personal identifiers were removed before patient data were entered into the computer and only aggregate data are presented.

1 Lee CA, Webster A, Griffiths PD, Kernoff PBA. Symptomless HIV infection after more than ten years [letter]. Lancet 1990;335:426.

Lee CA, Phillips A, Elford J, Miller EJ, Bofill M, Griffiths PD, et al. The natural history of human immunodeficiency virus infection in a haemophilic cohort. Br J Haematol 1989;73:228-34

Phillips A, Lee CA, Elford J,Janossy G, Bofill M, Timms A, et al. Prediction of progression to AIDS by analysis of CD4 lymphocyte counts in a haeof progression to AIDS by analysis of
mophilic cohort. AIDS 1989;3:737-41.

4 Chophilic cohort. AIDS 1989;3:737-41. longevity and causes of death among persons with hemophilia A. Am J Hematol 1994;45:112-21.

5 Quintana M, del Amo J, Barrasa A, Perez-Hoyos S, Ferreros I, Hernandez F, et al. Progression of HIV infection and mortality by hepatitis $\mathrm{C}$ infection in patients with haemophilia over 20 years. Haemophilia 2003;9:605-12.

(Accepted 5 September 2005)

doi 10.1136/bmj.38604.468785.DE

\section{Endpiece}

\section{Preservation of the teeth}

Those who love sugar and eat it often rarely have good teeth. Confections, dragees [French: a sweetmeat enclosing a drug-thus a sugar based medicine] and all sugars contribute ... to the destruction of the teeth. The most common cause of the loss of teeth is the negligence of those people who do not clean them when they might. Tartar (Fr: tartre: scale, fur-thus calculus, plaque) is one of the greatest enemies of the teeth.

Pierre Fauchard (c 1678-1761). Quotations from The Surgeon Dentist or Treatise on the Teeth. Translated from the 2nd edition, 1746, by Dr Lilian Lindsay (1871-1960). London: Butterworth, 1946

Submitted by Don Sarll, retired consultant in dental public health, High Wycombe 